\title{
Gram-Negative Endotoxin Administration Decreases Hepatic Drug-Metabolizing Enzymes during Development in Rats
}

\author{
BABASAHEB R. SONAWANE ${ }^{(37)}$ AND SUMNER J. YAFFE \\ Departments of Pediatrics and Pharmacology, University of Pennsylvania, School of Medicine, and \\ The Children's Hospital of Philadelphia, Philadelphia, Pennsylvania, USA
}

\section{Summary}

The frequency of gram-negative infections and endotoxemia in the perinatal period prompted an investigation of the effects of endotoxin (Escherichia coli 026B6) on hepatic drug metabolism. Gravid female rats given injections IP with different dosages of lipopolysaccharide during late pregnancy resulted in significant depression of the liver microsomal cytochrome $P-450$ dependent monooxygenase activities. The acute administration of endotoxin to mothers $(1.4 \mathrm{mg} / \mathrm{kg}$ on seventh day after parturition) significantly decreased the hepatic activity of aminopyrine demethylase and contents of cytochrome P-450 of suckling neonates and mothers. However, chronic administration of endotoxin $(0.2 \mathrm{mg} / \mathrm{kg} /$ day for 7 days) to lactating mothers did not alter neonatal enzyme activities. When neonates themselves were given injections of endotoxin $(1.0 \mathrm{mg} / \mathrm{kg})$ at 7,16 , and 27 days of age, a significant reduction in levels of mixed function oxidase enzymes was observed. These observations suggest that the ability of mothers and neonates to metabolize drugs is significantly decreased upon exposure to endotoxin, and this demands careful evaluation of drug disposition studies in gram-negative sepsis.

\section{Speculation}

Gram-negative bacterial infections with accompanying endotoxemia represent an increasing clinical concern especially in pregnant women and children requiring a number of drugs. Endotoxin could possibly modify the host response to drug metabolism and action. This could be significant in evaluating drug toxicity of clinically used therapeutic agents used in treatment of bacterial infections. In view of this hypothesis and of well-documented liver function abnormalities, we investigated the effects of endotoxin upon the activities of rat hepatic drug-metabolizing enzymes (in vitro) during development.

Endotoxemia accompanying gram-negative bacterial infections is a serious life-threatening condition which frequently occurs in pregnant women, children, and adults. Endotoxin, a soluble lipopolysaccharide cell wall constituent of gram-negative bacteria, is released into body fluids during infections by these organisms. The complications of pregnancy result in an occurrence of maternal urinary tract infections and endotoxemia leading to the birth of infants with neurological defects (21). Endotoxin has been shown to induce placental damage and abortion in experimental animals (25). Recently, Aballi et al. (1) demonstrated significant hepatic changes in rabbit liver after a single dose of endotoxin which prepares the animal for the Shwartzman reaction. Several other investigators also demonstrated liver functions abnormalities ( 3 , $11,32)$ and diffused necrotic lesions $(8,12,14,19)$ upon endotoxin administration in several species of animals including humans. The critical step leading to the development of shock is probably the direct injury of many types of host cells by microbial products. Bacterial endotoxins are the prototype of these substances for animal experimental investigations.

A number of therapeutic agents which are metabolized by liver are utilized in treatment of endotoxemia. However, very little is known about how the ability of the liver to metabolize drugs is altered upon administration of endotoxin. Using endotoxin derived from $E$. coli, we have previously demonstrated a decrease in the hepatic microsomal mixed-function oxidase enzyme activities of adult male (10) and female rats and also an increased hexobarbital sleeping time in male rats (34). We further report the effects of gram-negative bacterial endotoxin upon rat hepatic microsomal, drug-metabolizing enzymes during pregnancy and postnatal development.

\section{MATERIALS AND METHODS}

\section{ANIMALS AND TREATMENT}

Sprague-Dawley rats (CD strain) were used in these experiments. Rats were date bred to sperm-positive test, or gravid females were obtained from Charles River Breeding Laboratories (Wilmington, MA) at 14 days of gestation and housed separately. Throughout pregnancy and lactation, the rats had free access to food (Purina laboratory chow; Ralston Purina Co., St. Louis, MO) and water. The endotoxin preparation was lyophilized purified lipopolysaccharide from Escherichia coli, serotype 026B6 (Difco Laboratories, Detroit, MI). Endotoxin was administered IP in sterile pyrogen-free isotonic saline. The control group of animals received an equal volume of saline. Experimental protocols and treatment schedule are included in "Results."

\section{PREPRATION OF MICROSOMES AND ENZYME DETERMINATIONS}

The liver microsomal preparations were made as described previously (17) and resuspended in $150 \mathrm{mM}$ tris- $\mathrm{HCl}$ buffer (pH 7.4).

Liver microsomal cytochrome P-450 was determined by the method of Omura and Sato (23) with the assumption of an extinction coefficient of 91 mmoles $^{-1} \mathrm{~cm}^{-1}$ for the carbon monoxide-cytochrome P-450 complex absorbing at $450 \mathrm{nM}$. Cytochrome $b_{5}$, was determined with extinction coefficient of 110 mmoles ${ }^{-1} \mathrm{~cm}^{-1}$ measuring absorbance difference between 427 and $500 \mathrm{nM}$ (30). An Aminco Dw-2-UV-VIS Spectrophotometer was used for cytochrome P-450 and $b_{5,}$ measurements. An in vitro assay of aminopyrine $N$-demethylase with the production of formaldehyde was performed according to the Nash procedure (20) as modified by Orrenius (24). Aniline (AN) hydroxylase activity was determined by the method of Dixon et al. (7) in which p-aminophenol production was monitored. Benzo(a)pyrene (BP) hydrox- 
ylase activity was determined by the method of Gielen et al. (9). BP metabolism was measured as relative fluorescence at $523 \mathrm{~nm}$ with an excitation wavelength of $396 \mathrm{~nm}$ and compared to serial dilutions of 3-hydroxy-BP taken through the assay. The specific activity of NADPH cytochrome $c$ reductase was determined as described by Phillips and Langdon (26). The rate of appearance of reduced cytochrome $c$ was measured by following the absorbance change at $550 \mathrm{~nm}$ in a Beckman-(DU)-Guilford recording spectrophotometer, and an extinction coefficient of $19.1 \mathrm{mmoles}^{-9}$ $\mathrm{cm}^{-1}$ was used in calculating the absolute amount of cytochrome $c$ reduced per min per $\mathrm{mg}$ of microsomal protein. UPD-glucuronyltransferase was measured as described previously (18) by estimating spectrophotometrically the amount of $p$-nitrophenol glucuronide formed using $0.9 \mathrm{mM} p$-nitrophenol and Triton X-100activated microsomes. Liver microsomal protein concentration was determined by the procedure of Lowry et al. (16) with crystalline bovine serum albumin as the protein standard.

The data presented here were obtained from a minimum of 4 to 6 individual animals and expressed as either nmoles $/ \mathrm{mg}$ protein (cytochrome P-450 and $b_{5}$ ) and nmoles $/ \mathrm{min} / \mathrm{mg}$ protein (aminopyrine $N$-demeihylase and AN hydroxylase), mean \pm S.D., or percentage of control activity.

Statistical comparisons were made using Students' $t$ test; $P$ 's of $<0.05$ were considered significant.

\section{RESULTS}

\section{PREGNANCY}

Gravid female rats were given injections IP of $0.1,0.5$, and 1.0 $\mathrm{mg} / \mathrm{kg}$ (body weight) doses of endotoxin at 18 days of gestation and sacrificed $24 \mathrm{hr}$ later when liver microsomal enzyme determinations were made. The data are presented in Table 1 . Using $1.0 \mathrm{mg} / \mathrm{kg}$ endotoxin dose IP, 20 to $25 \%$ mortality of pregnant mothers was observed. Essentially, endotoxin administration significantly decreased the hepatic microsomal cytochrome P-450, $b_{5}$, and mixed function oxidation reactions. However, significant dose-dependent decrease in liver microsomal mixed-function oxidase enzymes by endotoxin was not observed. In other experimental protocol, we examined the possibility that prenatal administration IP of endotoxin might decrease the liver microsomal, mixed-function oxidase enzyme activities of developing animals. Pregnant rats were given injections IP with a $0.5 \mathrm{mg} / \mathrm{kg}$ dose of endotoxin IP on 7, 11, and 15 days of gestation, and liver microsomal enzyme activities were measured postnatally on the seventh and 21 st days in lactating mothers and their pups. We did not observe any significant changes in their (mothers' or pups') liver microsomal cytochrome P.450 and $b_{5}$ contents, aminopyrine $N$ demethylase, AN hydroxylase, BP hydroxylase, $p$-nitrophenolUDP-glucuronyltransferase, or NADPH-cytochrome $c$ reductase activities (data not shown).

Table 1. Decreased hepatic microsomal drug-metabolizing enzyme activities in pregnant rats by different doses of endotoxin ${ }^{1}$

\begin{tabular}{lcccc}
\hline \multicolumn{4}{c}{ Enzyme } & \multicolumn{4}{c}{ Endotoxin $(\mathrm{mg} / \mathrm{kg})$} \\
\cline { 2 - 5 } & Controls & 0.1 & $0.5^{3}$ & $1.0^{3}$ \\
\hline $\begin{array}{c}\text { Aminopyrine } \\
\text { demethylase }\end{array}$ & $3.20 \pm 0.48^{4}$ & $83^{5}$ & 69 & 65 \\
AN hydroxylase & & & & \\
Cytochrome P-450 & $0.34 \pm 0.08$ & $41^{3}$ & 35 & 30 \\
Cytochrome $b_{5}$ & $0.55 \pm 0.06$ & $71^{3}$ & 65 & 63 \\
\hline
\end{tabular}

${ }^{1}$ Endotoxin $(0.1,0.5$, or $1.0 \mathrm{mg} / \mathrm{kg}$ body weight) was administered IP on the 18th day of gestation, and liver microsomal enzyme measurements were made $24 \mathrm{hr}$ later.

${ }^{2}$ nmoles of product formed per $\mathrm{mg}$ microsomal protein per min or nmoles of cytochrome $\mathrm{P}-450$ or $b_{5}$ contents per $\mathrm{mg}$ of microsomal protein.

${ }^{3}$ Significant from control, $P \leq 0.05$.

${ }^{4}$ Mean \pm S.D.

${ }^{5}$ Values are percentage of control activity.

\section{LACTATING MOTHERS AND SUCKLING NEONATES}

The purpose of this experiment was to evaluate the effects of acute or short-term chronic administration of endotoxin upon maternal and neonatal liver microsomal drug-metabolizing enzyme activities (possible endotoxin excretion via milk). Three groups of mothers were given injections immediately upon parturition with an IP dosage of endotoxin as (1) control, pyrogenfree saline only; (2) acute, endotoxin ( $1.4 \mathrm{mg} / \mathrm{kg}$ body weight) given on the seventh day after delivery; and (3) chronic, endotoxin $(0.2 \mathrm{mg} / \mathrm{kg}$, body weight) given daily for 7 days after delivery. In a preliminary experiment, mothers were given injections IP immediately postpartum with a $0.5 \mathrm{mg} / \mathrm{kg}$ dose of endotoxin. We observed 100\% mortality within 6 to $8 \mathrm{hr}$. Therefore, the chronic dose of endotoxin $(0.2 \mathrm{mg} / \mathrm{kg}$ per day for 7 days) was chosen. Lactating mothers and their neonates were sacrificed $24 \mathrm{hr}$ after the last dose of endotoxin administration. Livers were removed and processed for microsomal preparations, and microsomal, mixed-function oxidase enzyme activities were determined as described earlier.

The acute administration of endotoxin significantly decreased aminopyrine $N$-demethylase activity almost by $50 \%$ and cytochrome P-450 and $b_{5}$ levels by $25 \%$ from control group. However, chronic administration of endotoxin slightly stimulated the enzyme activities. AN hydroxylase enzyme activity was not affected by both treatments of endotoxin (Table 2 ).

The data on the effects of acute and chronic maternal administration of endotoxin on hepatic drug metabolism of suckling neonates are presented in Table 3 . Chronic administration of

Table 2. Rat hepatic microsomal drug-metabolizing enzymes decreased by acute dose but increased by chronic administration of endotoxin to lactating mothers ${ }^{1}$

\begin{tabular}{lrcc}
\hline & \multicolumn{3}{c}{ Endotoxin } \\
\cline { 2 - 4 } \multicolumn{1}{c}{ Enzyme } & Controls & Acute & Chronic \\
\hline Aminopyrine & $4.43 \pm 0.05^{3}$ & $53^{4}$ & $114^{4}$ \\
$\quad$ demethylase & & & \\
AN hydroxylase $^{2}$ & $0.36 \pm 0.03$ & 100 & 100 \\
Cytochrome P-450 $^{5}$ & $0.57 \pm 0.03$ & $75^{4}$ & $118^{4}$ \\
Cytochrome $b_{5}$ & $0.59 \pm 0.05$ & $78^{4}$ & 112 \\
\hline
\end{tabular}

' Values are a percentage of control activity. Mothers were given injections IP postpartum with endotoxin as control-pyrogen-free saline only; acute, $1.4 \mathrm{mg} / \mathrm{kg}$ on the seventh day after delivery; and chronic, 0.2 $\mathrm{mg} / \mathrm{kg}$ given daily for 7 days after delivery. Liver microsomal enzyme measurements were made $24 \mathrm{hr}$ later.

${ }^{2}$ See legend to Table 1.

${ }^{3}$ Mean \pm S.D.

${ }^{4}$ Significant from control, $P<0.05$.

${ }^{5}$ See legend to Table 1 .

Table 3. Effects of acute and chronic maternal administration of endotoxin on hepatic drug-metabolizing enzymes of suckling neonates

\begin{tabular}{lccc}
\hline \multicolumn{1}{c}{ Enzyme } & \multicolumn{3}{c}{ Endotoxin' } \\
\cline { 2 - 4 } \multicolumn{1}{c}{ Controls } & \multicolumn{1}{c}{ Acute } & Chronic \\
\hline $\begin{array}{c}\text { Aminopyrine } \\
\quad \text { demethylase }\end{array}$ & $2.98 \pm 0.3^{2}$ & $3.40 \pm 1.2$ & $2.3 \pm 0.6$ \\
AN hydroxylase & $0.44 \pm 0.05$ & $0.40 \pm 0.07$ & $0.40 \pm 0.05$ \\
Cytochrome P-450 & $0.65 \pm 0.07$ & $0.57 \pm 0.02^{3}(73 \%)^{4}$ & $0.63 \pm 0.05$ \\
Cytochrome $b_{5}$ & $0.51 \pm 0.06$ & $0.39 \pm 0.03(76 \%)^{4}$ & $0.50 \pm 0.04$ \\
\hline
\end{tabular}

'Acute $(1.4 \mathrm{mg} / \mathrm{kg})$ and chronic $(0.2 \mathrm{mg} / \mathrm{kg})$ endotoxin for 7 days IP to mothers on postpartum. For details, see legend to Table 2 and "Results."

${ }^{2}$ Mean \pm S.D.

${ }^{3}$ Significant from control, $P<0.05$.

${ }^{4}$ Numbers in parentheses, percentage of control. Enzyme specific activities or cytochrome P-450 and $b_{5}$ contents are as expressed under Table 1 . 
endotoxin to mothers did not result in any significant effect on liver microsomal, mixed-function oxidase enzymes of neonatal rats. However, an acute dose of endotoxin $(1.4 \mathrm{mg} / \mathrm{kg})$ to mothers on the seventh postpartum day significantly decreased aminopyrine $\mathrm{N}$-demethylase activity and contents of cytochrome P-450 and $b_{5}$.

\section{POSTNATAL LIFE}

We further investigated the effects of endotoxin on liver microsomal, mixed-function oxidase enzymes during postnatal development. Young animals were given injections IP with a single 1.0 $\mathrm{mg} / \mathrm{kg}$ dose of endotoxin on 7,16 , or 27 days of age. Animals were sacrificed $24 \mathrm{hr}$ later when liver microsomal enzyme determinations were performed. Endotoxin $(1.0 \mathrm{mg} / \mathrm{kg})$ exposure IP on 16 and 27 days of age significantly increased liver-body weight ratio and decreased liver microsomal protein on 7 and 16 days of age (Table 4). Furthermore, hepatic, mixed-function oxidase enzymes and cytochrome P-450 and $b_{5}$, levels were significantly decreased at each time period of development. The sensitivity to the endotoxin effect (decline) on mixed function oxidase parameters decreased with developmental age (Table 5).

\section{DISCUSSION}

Recently, Nolan (22) discussed the role of endotoxins in liver injury and its hepatic and extrahepatic manifestations in certain liver diseases. Endotoxins have also been incriminated in the profuction of acute hepatic failure (33). The present studies demonstrate that acute administration of endotoxin during late pregnancy decreases rat hepatic microsomal mixed-function oxidase enzyme activities. However, the extent of decrease in liver microsomal, mixed-function oxidase enzymes was less conspicuous in pregnant animals as compared to previous adult animal data $(10,34)$. The possible explanation for this observation could be increased levels of circulating estrogens during late pregnancy protecting endotoxin effects. Numerous studies have indicated

Table 4. Increase in liver/body weight ratio and decrease in microsomal protein ${ }^{1}$ by endotoxin ${ }^{2}$ during postnatal development

\begin{tabular}{|c|c|c|c|c|c|c|}
\hline \multirow[b]{3}{*}{ Treatment } & \multicolumn{6}{|c|}{ Postnatal age (days) } \\
\hline & \multicolumn{2}{|c|}{7} & \multicolumn{2}{|c|}{16} & \multicolumn{2}{|c|}{27} \\
\hline & $\mathrm{L} / \mathrm{B}^{: 3}$ & Protein & $\mathrm{L} / \mathrm{B}$ & Protein & $L / B$ & Protein \\
\hline ontrol & 3.8 & $15.0^{4}$ & 3.2 & 18.6 & 4.9 & 18.4 \\
\hline Endotoxin & 4.4 & $11.2^{5}$ & $3.5^{5}$ & $16.7^{5}$ & $5.7^{5}$ & 17.2 \\
\hline$\%$ of change & 117 & 25 & 108 & 11 & 117 & 7 \\
\hline
\end{tabular}

' Values are $\mathrm{mg}$ microsomal protein per $\mathrm{g}$ of wet liver weight.

${ }^{2}$ Endotoxin dose $(1.0 \mathrm{mg} / \mathrm{kg} \mathrm{IP})$ given $24 \mathrm{hr}$ before sacrifice.

${ }^{3} \mathrm{~L} / \mathrm{B}$, liver/body weight ratio.

${ }^{4}$ Mean \pm S.D.

${ }^{5}$ Significant from control values, $P \leq 0.05$.

Table 5. Decrease in rat hepatic, mixed-function oxidase enzymes during postnatal development by endotoxin'

\begin{tabular}{lllc}
\hline & \multicolumn{3}{c}{ Postnatal age (days) } \\
\cline { 2 - 4 } \multicolumn{1}{c}{ Enzyme } & 7 & $16^{2}$ & 27 \\
\hline $\begin{array}{l}\text { Aminopyrine } \\
\text { demethylase }\end{array}$ & $78^{2}$ & 48 & $34^{2}$ \\
AN hydroxylase & N.D.3 & 28 & 6 \\
Cytochrome P-450 & $56^{2}$ & 32 & $25^{2}$ \\
Cytochrome $b_{5}$ & $32^{2}$ & 26 & $20^{2}$ \\
\hline
\end{tabular}

${ }^{1}$ Values are a percentage of control activity. Endotoxin dose $(1.0 \mathrm{mg} /$ $\mathrm{kg}$ IP) given $24 \mathrm{hr}$ before sacrifice (see "Results").

${ }^{2}$ Significantly different from control, $P<0.05$.

${ }^{3}$ N.D., not detectable. that pharmacologic doses of steroids have a salutory effect in bacteremic and endotoxic shock in the rat (27), dog (15), and subhuman primate (31). A variety of hemodynamic and membrane-stabilizing effects have been postulated to explain the beneficial action of steroids in septic shock (28). Our observation on $100 \%$ mortality of mothers right after delivery with a dose of endotoxin $(0.5 \mathrm{mg} / \mathrm{kg})$ suggests that their susceptibility to endotoxin increases markedly compared to adult females (dose lethal to $90 \%$ of the animals, $15 \mathrm{mg} / 100 \mathrm{~g}$ ).

We also measured placental cystein aminopeptidase (6) activity as a biochemical marker of placental function in control and endotoxin-treated $(1.0 \mathrm{mg} / \mathrm{kg}$ ) pregnant mothers ( 19 days of gestation). The specific enzyme activity (nmoles $/ \mathrm{min} / \mathrm{mg}$ protein) was significantly decreased by $32 \%$ from the control in the endotoxin-treated group (control, $25.5 \pm 2.3$ versus endotoxin treated, $17.5 \pm 2.6$ ). This preliminary data suggests possible placental damage by a low dose of endotoxin administration to mothers.

It was thought that endotoxin administration to mothers right after delivery could alter hepatic drug metabolism capacity of suckling neonates via a possible excretion of endotoxin through milk. However, chronic administration of endotoxin to mothers after delivery did not decrease the hepatic drug-metabolizing enzymes of neonates. An acute dose of endotoxin decreased mixed-function oxidase enzymes via a possible excretion of endotoxin through milk. The failure of chronic endotoxin administration in decreasing drug-metabolizing enzymes could be due to the development of nonspecific tolerance. In fact, animals can be made nonspecifically tolerant to a variety of endotoxins by giving increasingly large doses of endotoxins over a short period of time (22). Jennings et al. (13) made dogs tolerant over a 2-wk to 2month period and were able to almost completely protect them against hemodynamic and biochemical effects of a normally lethal endotoxin challenge. The mechanism of this nonspecific tolerance is not well understood.

The effects of endotoxin on liver microsomal, mixed-function oxidase enzymes were more evident and decreased drug-metabolizing enzyme activities with age compared to adult male or female rats as previously reported $(10,34)$. This probably is related to the physiologic and biochemical maturation of the organism and agerelated increase in resistance to infections.

We are investigating the mechanism of inhibition of hepatic microsomal cytochrome P-450 and dependent drug oxidation reactions by endotoxin. It is probably being converted in vivo to an inhibitor of mixed-function oxidase enzymes. In support of this statement, we observed that a time lapse of $6 \mathrm{hr}$ is required to inhibit liver microsomal cytochrome $\mathrm{P}-450$ upon in vivo administration of endotoxin. Furthermore, endotoxin does not directly inhibit cytochrome P-450 or aminopyrine $N$-demethylase activity on addition in vitro incubations. However, preincubation of endotoxin ( $100 \mu \mathrm{g} / \mathrm{mg}$ microsomal protein) with NADPH-generating system supplemented with EDTA $(1 \mathrm{mM})$ and microsomes for 30 min, significantly decreases the level of cytochrome P-450 and aminopyrine $N$-demethylase activity (34) after accounting for lipid peroxidation by NADPH itself (29). These observations suggest that liver microsomal membrane lipid peroxidation may be enhanced by endotoxin. The mechanism for the depression of hepatic cytochrome P-450 by endotoxin has been suggested by Bissell and Hammaker $(4,5)$. They observed marked enhancement of the degradation of cytochrome $\mathrm{P}-450$ heme by reversible dissociation of heme moiety from its apoprotein and by mixing with exogenously synthesized heme which regulates $\delta$-amino-levulinic acid synthetase activity.

\section{CONCLUSION}

Acute administration of gram-negative bacterial endotoxin during pregnancy and postnatal period decreases rat liver drug-metabolizing enzymes. These observations suggest clinically possible adverse drug reactions and demand a careful evaluation of drug disposition studies in neonates with gram-negative infections. 


\section{REFERENCES AND NOTES}

1. Aballi, A. J., Karayalcin, G., Costales, F., Gubernick, F., and Lanzkowsky, P.: Liver damage in rabbits from administration of a single dose of gram-negative endotoxin. Pediatr. Res., 12: 646 (1978).

2. Abernathy, R. S.: Homologous and heterologous resistance of mice given bacterial endotoxins. J. Immunol., 78: 387 (1957).

3. Abrams, J. S., Hopkins, R. M., Palmer, R., and Simcone, F. A.: Effect of phenoxibenzamine in endotoxin shock in dogs. II. Metabolic changes. J. Trauma, 9: 614 (1969).

4. Bissell, D. M., and Hammaker. L. E.: Cytochrome P-450 heme and the regulation of hepatic heme oxygenase activity. Arch. Biochem. Biophys.. 176: 91 (1976).

5. Bissell, D. M.. and Hammaker, L. E.: Cytochrome P-450 heme and the regulation of $\alpha$-aminolevulinic acid synthetase in the liver. Arch. Biochem. Biophys.. 176: 103 (1976).

6. Christensen, A., and Hagelid, P. E.: Hormone and enzyme assays in pregnancy. V. A rapid method for measuring placental cystine aminopeptidase using $\mathrm{L}$ cystine-bis-p-nitroanilide as the substrate. Separatum Acta Endocrinol., 76: 1 (1974).

7. Dixon, R. L., Har, L. G., Rogers, L. A., and Fouts, J. R.: The metabolism of drugs by liver microsomes from alloxan-diabetic rats: long term diabeces. J. Pharmacol. Exp. Ther., 142: 312 (1963).

8. Gerber, J. E.: Pathological aspects of the local and generalized Shwartzman phenomenon. Am. J. Pathol., I1: 843 (1935).

9. Gielen, J. E., Goujon, F. M., and Nebert, D. W.: Genetic regulation of aryl hydrocarbon hydroxylase induction. J. Biol. Chem.. 247: 1125 (1972).

10. Gorodisher, R., Krasner, J., McDevitt, J. J., Nolan, J. P., and Yaffe. S. J.: Hepatic microsomal drug metabolism after administration of endotoxin in rats. Biochem. Pharmacol., 25: 351 (1976).

11. Griel, L. C.. Jr., Zarkower, A., and Eberhart, R. J.: Clinical and clinicopathological effects of Escherichia coli endotoxin in mature cattle. Can. J. Comp. Med. Vet. Sci., 39: 1 (1975).

12. Hardway, R. M., Chun, M. B., and Rutherford, R. B.: Histologic evidences of disseminated intravascular coagulation in clinical shock. Vasc. Dis., 2: 254 (1965).

13. Jennings, P. B., Simmons, R. L.. Sleeman, H. K., and Hardway, R. M.: Hemodynamic, biochemical and coagulation alterations in endotoxin shock: modification by included tolerance in the dog. Ann. Surg.. 167: 204 (1968).

14. Levy, E., and Ruebner, B. H.: Hepatic changes produced by a single dose of endotoxin in the mouse: light microscopy and histochemistry. Am. J. Pathol.. 5l: 269 (1967).

15. Lillehei, R. C.. Longerbeam, J. K., and Bloch. J. H.: Physiology and therapy of bacteremic shock. Experimental and clinical observations. Am. J. Cardiol., 12: 599 (1963).

16. Lowry, O. H., Rosebrough, N. J., Farr, A. L., and Randall. R. J.: Protein measurement with the Folin phenol reagent. J. Biol. Chem., 193: 265 (1951).

17. Lucier, G. W., McDaniel, O. S., Bend. J. R.., and Faeder, E.: Effects of hycanthone and two of its chlorinated analogs on hepatic microsomes. J. Pharmacol. Exp. Ther., I86: 416 (1973)

18. Lucier, G. W.. Sonawane. B. R., and McDaniel, O. S.: Glucuronidation and deglucuronidation reactions in hepatic and extrahepatic tissues during perinatal development. Drug Metab. Dispos., 5: 279 (1977).
19. Margaretten, W., McKay, D. G., and Phillips, L. L.: The effect of heparin on endotoxin shock in the rat. Am. J. Pathol., SI: 61 (1967).

20. Nash, T.: The colorimetric estimation of formaldehyde by means of the Hantzsch reaction. Biochem. J., S5: 416 (1953).

21. Niswander, K. R., and Gordon, M.: The Women and Their Pregnancies. The Collaborative Perinatal Study of the National Institute of Neurological Diseases and Stroke. pp. 252-256 (W. B. Saunders Co., Philadelphia, 1972).

22. Nolan, J. P.: The role of endotoxin in liver injury. Gastroenterology, 69: 1346 (1975).

23. Omura, T., and Sato, R.: The carbon monoxide-binding pigment of liver microsomes I. Evidence for its hemoprotein nature. J. Biol. Chem., 239: 2370 (1964)

24. Orrenius, $S$.: On the mechanism of drug hydroxylation in rat liver microsomes. J. Cell Biol., 26: 713 (1965).

25. Ornoy, A., and Altshuler, G.: Maternal endotoxemia, fetal anomalies and central nervous system damage: a rat model of a human problem. Am. J. Obstet. Gynecol., 124: 196 (1976).

26. Phillips, A. H., and Langdon, R. G.: Hepatic triphosphopyridine nucleotidecytochrome $c$ reductase isolation characterization in kinetic studies. J. Biol. Chem.. 237: 2652 (1962).

27. Pitcairn. M., Schuler, J., Erve, P. R., Holtzman, S., and Schumer, W. : Glucocorticoid and antibiotic effect on experimental gram-negative bacteremic shock. Arch. Surg., 110: 1012 (1975).

28. Rosenberg, J. C., Lillehei, R. C., Longerbeam, J., and Zimmermann, B.: Studies on hemmorrhagic and endotoxin shock in relation to vasomotor changes and endogenous circulating epinephrine, norepinephrine and serotonin. Ann. Surg.. 154: 611 (1961).

29. Schacter, B. A., Marver, H. S., and Meyer, U. A.: Heme and hemoprotein catabolism during stimulation of microsomal lipid peroxidation. Drug Metab. Dispos., I: 286 (1973).

30. Schenkman. J. B. Remmer, H., and Estabrook. R. W.: Spectral studies of drug interaction with hepatic microsomal cytochrome. Mol. Pharmacol., 3: 113 (1967).

31. Schumer, W.: Steroids in the treatment of clinical septic shock. Ann. Surg., 184: 333 (1976).

32. Sleeman. H. K., Jennings, P. B., and Hardway. R. M.: Evaluation of biochemical changes associated with experimental endotoxemia. I. Transaminase activity. Surgery, 61: 945 (1967).

33. Wilkinson, S. P., Arroyo, V., Gazzard, B. G., Moodie, H., and Williams, R. Relationship of renal impairment and hemorrhagic diathesis to endotoxemia in fulminant hepatic failure. Lancet, $1: 521$ (1974).

34. Yaffe, S. J., and Sonawane, B. R.: Inhibition of rat hepatic microsomal drug metabolizing enzymes by endotoxin. Fed. Proc., 37: 745 (1978).

35. Presented in part at the Annual Meeting of the Society of Pediatric Research. New York, 1978. Published as an abstract in Pediatric Research, 12: 408 (1978)

36. The authors are indebted to Mr. Jack Keammerer for his technical assistance.

37. Requests for reprints should be addressed to: Dr. B. R. Sonawane, Research Assistant Professor of Pediatrics and Pharmacology, Division of Clinical Pharmacology. Children's Hospital of Philadelphia, 34th and Civic Center Blvd., Philadelphia, PA 19104 (USA).

38. This research was supported by NIH Grant HDI0063.

39. Received for publication July 16. 1979.

40. Accepted for publication December 17, 1979 